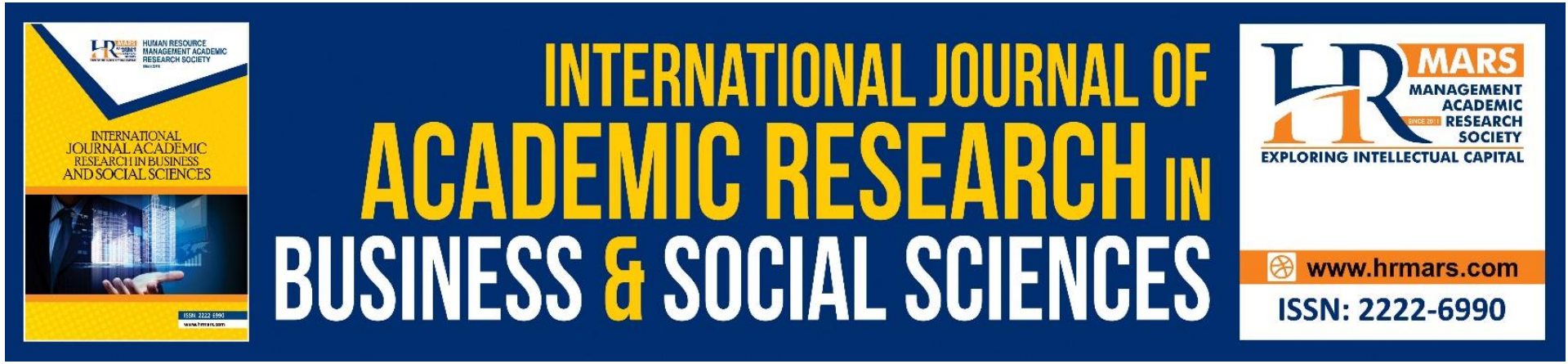

\title{
Language Learning Strategies Used for Reading Skill by Pupils in Selected Rural Schools in Sarawak
}

Donna Anak Dawi, Hana Bua' Hilary, Masliza David, Michelle Elaine Anak William Jospa, Wendy Kulan Anak Igai, Harwati Hashim

To Link this Article: http://dx.doi.org/10.6007/IJARBSS/v11-i6/10054

DOI:10.6007/IJARBSS/v11-i6/10054

Received: 19 April 2021, Revised: 21 May 2021, Accepted: 05 June 2021

Published Online: 20 June 2021

In-Text Citation: (Dawi et al., 2021)

To Cite this Article: Dawi, D. A., Hilary, H. B., David, M., Jospa, M. E. A. W., Igai, W. K. A., \& Hashim, H. (2021). Language Learning Strategies Used for Reading Skill by Pupils in Selected Rural Schools in Sarawak. International Journal of Academic Research in Business and Social Sciences, 11(6), 1379-1390.

Copyright: (c) 2021 The Author(s)

Published by Human Resource Management Academic Research Society (www.hrmars.com)

This article is published under the Creative Commons Attribution (CC BY 4.0) license. Anyone may reproduce, distribute, translate and create derivative works of this article (for both commercial and non-commercial purposes), subject to full attribution to the original publication and authors. The full terms of this license may be seen at: http://creativecommons.org/licences/by/4.0/legalcode

Vol. 11, No. 6, 2021, Pg. 1379 - 1390

http://hrmars.com/index.php/pages/detail/IJARBSS

JOURNAL HOMEPAGE

Full Terms \& Conditions of access and use can be found at http://hrmars.com/index.php/pages/detail/publication-ethics 


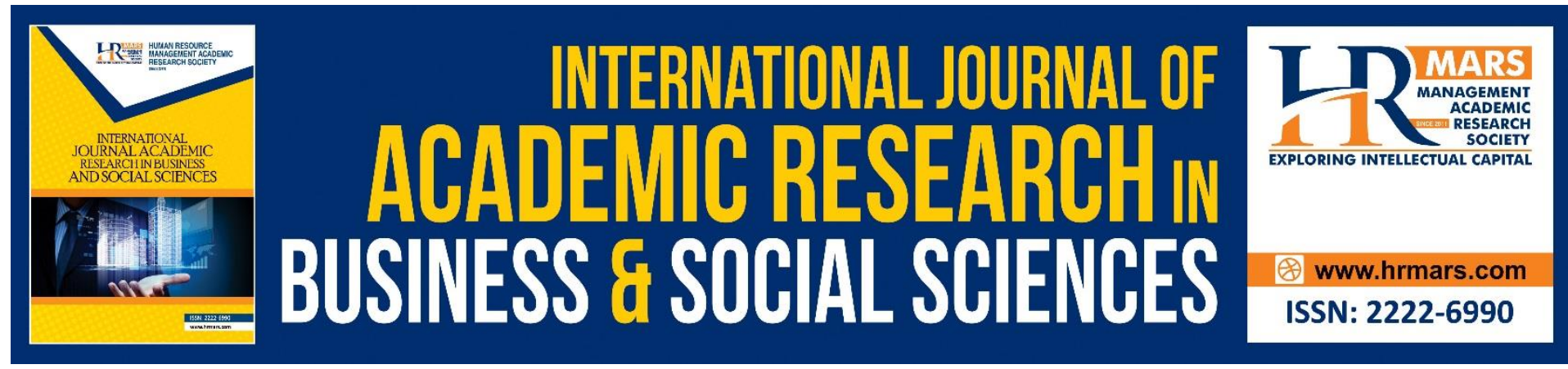

\title{
Language Learning Strategies Used for Reading Skill by Pupils in Selected Rural Schools in Sarawak
}

\author{
Donna Anak Dawi, Hana Bua' Hilary, Masliza David, Michelle \\ Elaine Anak William Jospa, Wendy Kulan Anak Igai, Harwati \\ Hashim \\ Faculty of Education, Universiti Kebangsaan Malaysia (UKM), Bangi, Selangor, Malaysia.
}

\begin{abstract}
Rural schools in Malaysia strive to progress on par with their counterparts in urban schools despite their differences. Pupils learning in the rural schools may not experience a similar level of exposure to English as the pupils in the urban schools. It is seen essential to understand the learning process experienced by pupils in rural schools to progress in learning. Language learning strategies are a crucial element in the learning process and action that aid the use and acquisition of language. It is hypothesized that one factor influencing the development of reading skills was the pupils' learning strategies. This study aims to examine the learning strategies used among rural primary school pupils in developing their reading skills. In this study, quantitative research design was administered through the use of survey. The data was collected through questionnaires of Young Learners' Language Strategy Use Survey by Andrew D. Cohen and Rebecca L. Oxford (2002). Four selected schools are situated in the rural areas of four districts in Sarawak. The data collected were analyzed quantitatively. The major finding of this study resulted in the two highest percentages of preferred language learning strategies by the pupils in the selected rural schools namely the affective strategy and the cognitive strategy. The findings will be able to benefit the educators by giving new insights on appropriate reading strategies that would impact optimally as well as improving the pupils' learning progress awareness concerning reading skill. This reflects on the current teaching of English reading skills and what can be done to give a more impactful reading outcome. On this basis, consideration of the types of reading materials, reading tasks and readers' aspects should be taken into account when designing reading lessons.
\end{abstract}

Keywords: Language Learning Strategies, Reading Skill, Rural Primary School, Affective Strategy, Cognitive Strategy

\section{Introduction}

In Malaysia, English holds the status of second language as stated in Article 152 which was taught compulsorily for eleven years from Standard One to Form Five (Hashimah, 2008; Nazri, 2013). Meanwhile, in Sarawak, English is one of the state's official languages beside Bahasa Malaysia (The Official Portal of Sarawak Government, 2018). For the majority of Sarawak 
people who practice the use of native language actively, English is considered to be their third language when they attend their formal education. With equal importance given to English, language learning becomes a crucial topic and constant challenge to the members of the education world. With equal importance given to English, efforts on promoting English at the state level as well as national level are endless. Some of the programs are skill-oriented in the effort to strengthen language individual skill. For example, the Highly Immersive Program or known as HIP was introduced by the Ministry of Education in 2016 to support English activities in school. The aim of the program is to create a highly immersive, language-rich environment that promotes the use of English in all schools (Maszlee, 2019). He elaborated further that students are exposed to the English language through a number of activities both inside and outside the classroom as part of the HIP. Under this program, one of the activities proposed for all schools nationwide is Let's Read Online. This program inculcates the reading habits and promotes the sense of sharing among the school community as this program is not confined to the responsibility of the school alone but supported with the collaboration with parents.

Study in language learning constantly grows parallel to the current demand in education. A branch under such study with consistent attention proven to have strong correlation is the second language acquisition and learning (Khamkhien, 2010). Given the importance of learning strategies in second language acquisition, much attention was given to explore the theories and the application of such learning strategies. Pioneers such as John Schumann, Avram Chomsky, Stephen Krashen, and Lev Vygotsky have all developed theories about how to learn a second language to a high level of proficiency (Friedrichsen, 2020) such as acculturation model, sociocultural theory, universal grammar hypothesis, interlanguage theory, Krashen's theory of second language acquisition, and the complexity theory (Menezes, 2013). Understanding second language acquisition might help mainstream teachers better serve their classrooms' culturally and linguistically diverse pupils. While extensive professional development is required to fully comprehend second language acquisition theory, several essential phases, theories, and teaching practises can be easily grasped and used (Yang, 2008). These theories have served as a strong foundation to many learning strategies applied in current language acquisition and learning.

The choice of learning strategy is influenced by many factors from previous research. Learning proficiency is one of the factors that affect the choice of learning strategy (Zare, 2012). Looking into reading skill specifically, pupils experience the reading process differently. Reading ability is one of the factors that influences reading attitude (Braden, 2012). Pupils face different challenges while reading according to their level of reading ability. A closer look into the actions taken by pupils while reading second language materials would give an insight to how they overcome the challenges while reading. With that direction in mind, it is an interesting branch to uncover pupils' preferred language learning strategies during reading. This research, therefore, attempts to explore the language learning strategies preferred by pupils in reading skill from four rural primary schools in Sarawak, Malaysia. This research will answer two research questions:

1. What are the most favoured language learning strategies used by pupils in the reading skill of rural primary schools?

2. What are the implications on teaching and learning of reading skill in the rural primary schools? 


\section{Literature Review}

Learning a new language does not come neither naturally nor easily. No one is born fluent in speaking but everyone needs to learn it. Nevertheless, somehow there seems to be differential success among language learners. Zare (2012) commented that some learners seemed to be more successful regardless of methods or teaching techniques. For example, in learning English language, some non-native speakers demonstrate high proficiency and fluency in the language while others could barely understand a word. The differential success among learners drives many researchers to investigate further how learners learn and what are the factors that contribute to the success of language learners.

\section{Language Learning Strategies}

Definitions

Specialists and researchers have construed wide and various meanings of strategies of language learning over the years. The definitions have been expanded to include a wider explanation as the strategies are further explored and repetitively studied. Technically speaking, Zare (2012) commented that the strategies referred to by many researchers globally actually refer to various behaviours among the language learners. Wenden (1987) describes learning strategies as the numerous operations employed by learners to make sense of their learning. Oxford (1990) posits learning strategies as specific steps taken by the learner to aid simpler, more rapid, fun and transferrable language learning. Williams and Burden (1997) maintain that learning strategies refer to several resources used by learners in different ways to complete or solve their tasks. Cohen (2014) describes language learning strategies as intentional thinking and doing of the language learners in fulfilling their numerous tasks. To summarize, language learning strategies refer to the operations, steps or measures taken by the learner to successfully acquire the target language. Lee (2010) proverbially likens learning strategy to tactics employed by sportsmen to win a game. The application of language learning strategies directly impacts the success of language learning.

\section{Categorizations}

Many researchers have proposed their own taxonomies of strategies of language learning. Rubin (1987) allotted strategies of language learning into three strategies namely 'learning, communication and social strategies'. Similarly, O' Malley et al. (1985) classified them into three groups namely 'metacognitive, cognitive and socio-affective strategies'. Stern (1992) proposed an expanded taxonomy which include five language learning strategies, which are 'management and planning, cognitive, communicative-experiential, interpersonal as well as affective strategies'. Nevertheless, of all the taxonomies of language learning strategies proposed, Lee (2010) commented that Oxford (1990) offers the most comprehensive taxonomy. Oxford (1990) posited two broad categories of language learning strategies namely direct and indirect strategies. Each broad category is broken down into subcategories whereby 'memory, cognitive and compensation strategies' fall under direct strategies while indirect strategies include 'metacognitive, affective and social strategies'. Overall, Oxford's taxonomy provides a comprehensive language learning strategy with sixty-two specific strategies branching out from the two broad categories and six subcategories. Nonetheless, despite each having their own distinct labeling, Zare (2012) pointed out that the majority of these propositions share similar classifications. In general, researchers find that learners who apply more strategies to complete tasks will be more successful in the tasks. Interestingly, this principle applies to all the variety of taxonomies of language learning strategies. Richard 
(1994) supported this statement and added that appropriate use of language learning strategies help learners to be successful in the tasks. In short, the number and appropriateness of language learning strategies contribute to the success of language acquisition.

\section{Findings of previous study}

There has been a lot of studies on learning and language learners over the past decades. Zare (2012) observed that language learning strategies have garnered great attention since the 1970s with the emergence of cognitive revolution. According to Dawadi (2017), past studies have focused on identifying the most widely-used language learning strategies among learners. The findings revealed that the top three strategies employed by learners include 'metacognitive, compensation and cognitive strategies'. Meanwhile, studies focusing on young learners showed that they tend to employ 'social, affective and compensation strategies' (Pfenninger \& Singleton, 2017). This is supported by Doro' \& Habok (2013) who reported the use of memory strategies are less prevalent among young learners. Chamot (2004) on the other hand, proposed that the learners' cultural settings influence the types of strategies they employ. Other than that, previous research also studied the relationship between language learning strategies and language proficiency. Findings by Liu (2010) as well as Platsidou \& Kantaridou (2014) revealed how language learning strategies play important roles in achieving language performance. Wu (2008) concurred this claim and pointed to cognitive strategy as being the most influential learning strategy in becoming a proficient language user. Additionally, findings by Rao (2016) showed that successful language learners are those who employ more language learning strategies as compared to the less successful learners.

\section{Good/ Successful Language Learners}

Success at acquiring the target language is determined by the learning strategies used by learners. Various research findings have repeatedly proven that the more language strategies employed, the better proficiency in the target language (Hong, 2006). According to Green and Oxford (1995), the wide variety of language learning strategies employed by the good language learners contribute to their growing proficiency. Griffiths (2003) also came to a similar finding and discovered a strong dynamic between the strategy use and the proficiency achieved. Meanwhile, Rubin (1975) proposed a detailed exploration of strategies used by good language learners is paramount to understanding the differential success among language learners. According to Rubin (1975), there are seven strategies employed by them. Firstly, they are a 'willing and accurate guesser'. The good guessers make use of all the clues provided in their setting to discern the meaning and intent of the communication. Secondly, they are driven to communicate and to learn from it. They try their level best to convey their meaning across, supplementing their language with circumlocution, gestures and paraphrases. Thirdly, successful language learners are frequently unencumbered. They readily accept making mistakes as their friends, and not foes in learning the language. Fourthly, they are alert to attend to form. They are sensitive with regards to language structure and processes the language input. Next, the fifth strategy employed by the good language learners is consistent practice. They frequently seek and seize opportunities to use the target language. The sixth strategy is personal and interpersonal monitoring. Good language learners consciously examine their and others' language use while simultaneously evaluating their learning progress. Finally, the seventh strategy employed by successful 
language learners is to focus on meaning. Besides grammar, they take note of other important elements such as the relationship of the participants, the mood of the speech and the rule of speaking.

\section{Research Methodology}

This research is using a quantitative research design. The data collected is numerical and analyzed by using frequency. It is presented in the form of a percentage. The survey consists of 16 short questionnaires that focus on reading skill in the English language. It is conducted using a survey tailored from the Young Learners' Language Strategy Use Survey (Cohen \& Oxford, 2002). The survey is also written and typed in two languages whereby Bahasa Malaysia and English were used. The survey was also using simpler words than the Young Learners' Language Strategy Use Survey to cater for different kinds of respondents with different proficiencies. The survey was online using Google Forms and hardcopies were distributed among respondents by the researchers to the selected schools. A total of 50 pupils from four selected primary schools in Sarawak participated as respondents in the study. There were 29 female and 21 male respondents respectively. Respondents were among Year 5 and Year 6 pupils. The respondents were of different proficiency in the English language and they have different socio-backgrounds as well.

\section{Sample}

This research used convenience sampling. Convenience sampling is defined as a type of nonprobability sampling in which people are sampled simply because they are "convenient" sources of data for researchers (Lavrakas, 2008). This method relies on data collected from population members who are conveniently available to participate in the study (Methodology, 2015). The survey was available to be answered online for convenience and some respondents responded to it using printed surveys and distributed among them. This is to cater to the lack of internet access for some respondents from other districts in Sarawak. Other than that, with the condition nowadays when schools are closed because of the Covid19 pandemic, using this type of sampling is practicable. Some respondents do not own ICT tools in order to do the survey online as well. The researchers gathered data from the responses through the survey which was adapted from the Young Learners' Language Strategy Use Survey by Cohen and Oxford (2002). The questionnaires were distributed to the selected 50 pupils and they were asked to return the questionnaires to the respective researchers from each district. The researchers collected the data in the span of three months.

\section{Findings \& Discussion}

The aim of this study is to identify pupils' most preferred reading skills strategies in order to improve their reading skills specifically in English Language. Responses were obtained from 50 pupils of four different rural schools in Sarawak. In response to the research objective, their responses were tabulated and were further analysed to determine the most preferred reading skill strategies by the respondents. The findings of this research will be discussed under three subsections namely 'What I do to read more', 'What I do to understand what I read' and 'What I do when I don't understand what I read. 
Table 1: What I do to read more

\begin{tabular}{|l|l|l|l|}
\hline Strategy & Agree & Neutral & Disagree \\
\hline 1. I read a lot in English Language. & $15 \%$ & $32 \%$ & $14 \%$ \\
\hline 2. I read for fun in English language. & $46 \%$ & $44 \%$ & $10 \%$ \\
\hline 3. I find things to read that interest me. & $84 \%$ & $16 \%$ & $0 \%$ \\
\hline 4. I look for things to read that are not too hard. & $66 \%$ & $28 \%$ & $6 \%$ \\
\hline
\end{tabular}

Based on the table above, pupils were asked what they do to read more. There were four statements provided and, in this section, the focus will be on determining what motivates pupils to read more in English. The highest percentage of responses was for statement 4 with the percentage of $84 \%$ or 42 out of 50 pupils. They responded that they read books that they find to interest them. $66 \%$ or 33 out of 50 pupils preferred to look for reading materials that are not too difficult for them to comprehend. Reading for pleasure or enjoyment scored $46 \%$ which equals 23 out of 50 pupils while only $15 \%$ or 27 out of 50 pupils responded they read a lot in English Language.

Based on the findings above, it can be concluded that in order for pupils to motivate themselves to read, they choose English reading materials in which the materials are not too difficult to be comprehended by them. Apart from that, a number of pupils stated that they read materials that they find to be interesting.

Table 2: What I do to understand what I read

\begin{tabular}{|c|c|c|c|}
\hline Strategy & Agree & Neutral & Disagree \\
\hline 1. I skim over a reading to get the main idea. & $32 \%$ & $46 \%$ & $22 \%$ \\
\hline 2. I look for important facts. & $56 \%$ & $28 \%$ & $16 \%$ \\
\hline 3. I read things more than once. & $54 \%$ & $30 \%$ & $16 \%$ \\
\hline 4. I look at the pictures and what is under the pictures. & $74 \%$ & $12 \%$ & $14 \%$ \\
\hline 5. I look at the headings. & $82 \%$ & $14 \%$ & $4 \%$ \\
\hline 6. I think about what will come next in the reading. & $74 \%$ & $14 \%$ & $4 \%$ \\
\hline 7. I stop to think about what I just read. & $30 \%$ & $40 \%$ & $30 \%$ \\
\hline 8. I underline parts that seem important. & $62 \%$ & $20 \%$ & $18 \%$ \\
\hline $\begin{array}{l}\text { 9. I mark the reading in different colours to help me } \\
\text { understand. }\end{array}$ & $36 \%$ & $30 \%$ & $34 \%$ \\
\hline 10. I check to see how much I understood. & $52 \%$ & $36 \%$ & $12 \%$ \\
\hline
\end{tabular}

In this section, pupils were asked what they do to understand what they have read. The responses obtained from the survey were tabulated as above. Based on the data, $82 \%$, which equals to 41 out of 50 pupils, prefer to look at the headings to help them understand the materials or articles read. Strategy 4 and strategy 6 shared a similar percentage of $74 \%$ or 37 out of 50 pupils. This shows that pupils prefer to look at the visuals provided in the materials to help them comprehend the texts better. They also find it is helpful to think of what will come next in the reading to comprehend the reading materials. The third highest response 
that was obtained from this section is $62 \%$ or 31 out of 50 pupils. Pupils preferred to underline the parts that seem important in the reading materials to help understand better.

Table 3: What I do when I don't understand what I read?

\begin{tabular}{|l|l|l|l|}
\hline Strategy & Agree & Neutral & Disagree \\
\hline $\begin{array}{l}\text { 1. I guess the meaning by using clues from other parts } \\
\text { of the passage. }\end{array}$ & $52 \%$ & $28 \%$ & $20 \%$ \\
\hline 2. I use a dictionary to find the meaning. & $70 \%$ & $8 \%$ & $22 \%$ \\
\hline
\end{tabular}

The responses obtained in the third section of the questionnaire were tabulated as above. From the data obtained, it is revealed that $70 \%$ of pupils, which equals 35 out of 50 pupils, choose to look up the meanings in the dictionary to overcome the difficulties while reading. $52 \%$ or 26 out of 50 pupils choose to employ contextual clues by guessing the meaning from other parts of the passage read.

The analyses of data revealed that pupils preferred to use cognitive strategies and affective strategies when it comes to reading.

Figure 1: Strategies Preferred by Pupils to Motivate Reading

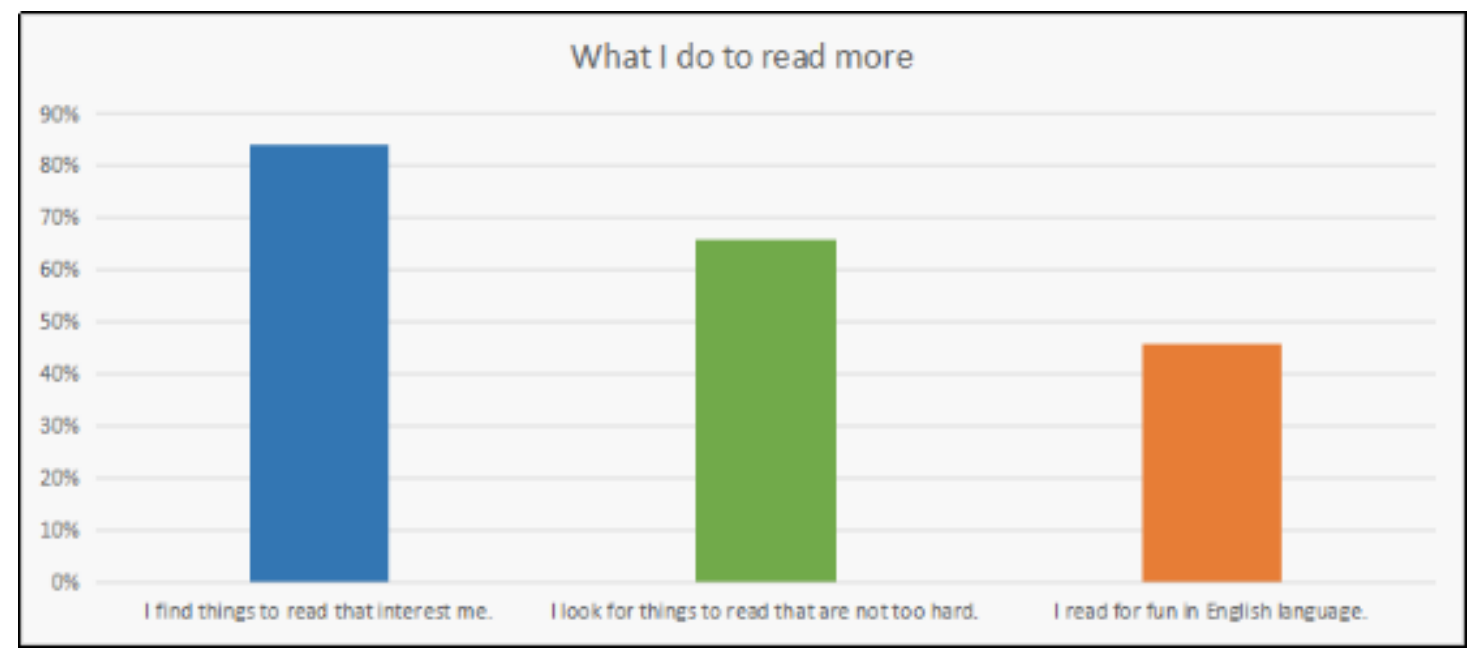

The results above revealed that pupils prefer to employ affective strategies in order to enhance their reading skill. Affective strategies in language learning can help pupils to identify negative feelings towards the target language, increase pupils' self-confidence and at the same time lower their anxiety while acquiring the language. Based on the findings, the three statements that scored the highest percentages are 'I find things to read that interest me', 'I look for things to read that are not too hard' and 'I read for fun in English Language'. These statements revealed that pupils chose to employ affective strategies in order to improve their reading skills in English. According to Oxford (1990) Classification of Language Learning Strategies, the affective strategies help to aid pupils monitor their emotions, motivation and attitude that are associated with learning. These strategies help to encourage them by lowering their anxiety while reading in the target language. External factors such as stress, anxiety and bad feeling towards the language learning may prevent pupils from acquiring the language. Therefore, in order to overcome these feelings, pupils tend to build positive feelings towards the language by reading materials that they find to be interesting. Furthermore, learning another language may cause pupils to experience several feelings and emotions 
(Stern, 1992). Most of the pupils did not use English language as their first language thus making them feel intimidated and causing them to feel inferior when using the language. They feel reluctant to use the language to avoid making mistakes which will lead to embarrassment. Hence, in order for them to overcome this situation, they prefer to read materials that are not too difficult to comprehend and read more for enjoyment. By doing so, pupils are able to gain their self-confidence and continue to read more in the target language on a more serious topic.

Figure 2: Strategies Preferred by Pupils to Facilitate Reading

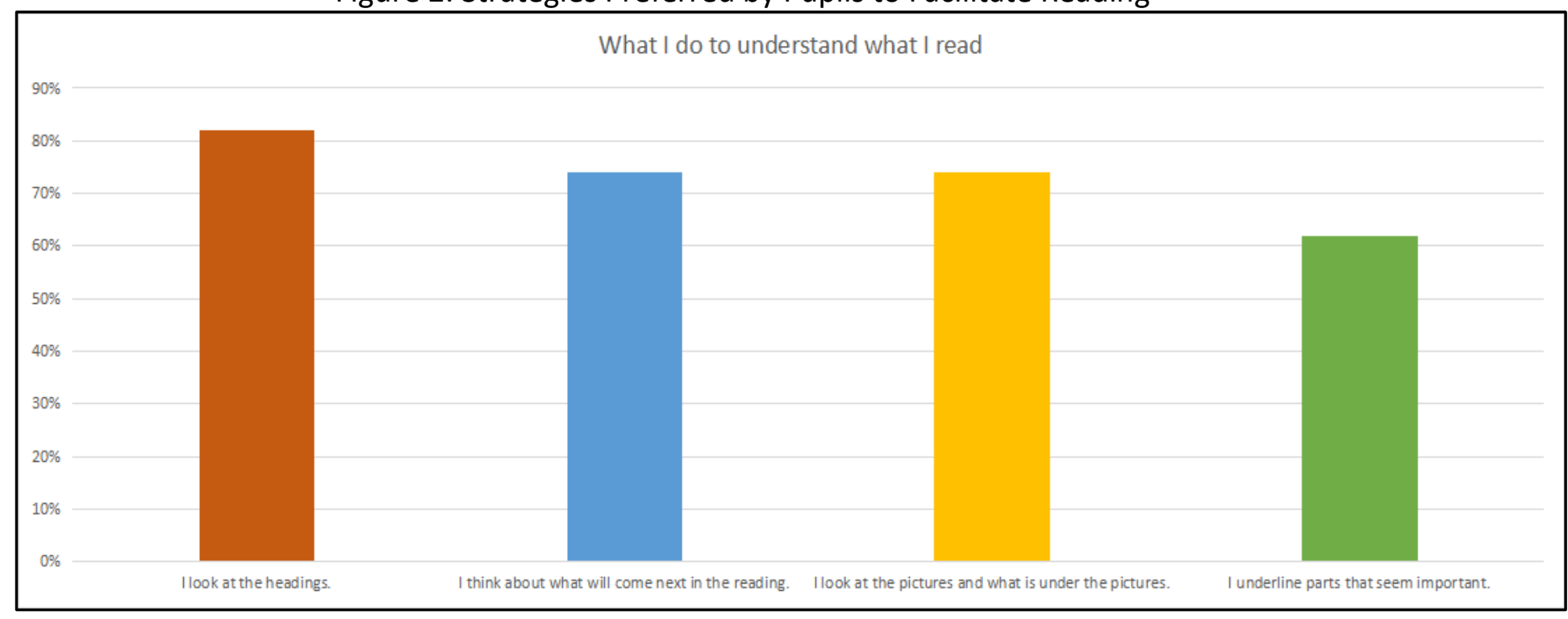

Figure 2 shows the four statements with the highest percentage value. The statements are ' look at the headings', 'I think about what will come next in the reading', 'I look at the pictures and what is under the pictures' and 'I underline parts that seem important'. Based on the results shown, it can be concluded that pupils prefer to employ cognitive strategies when it comes to overcoming difficulties in reading comprehension. Cognitive strategies is classified as one of the direct strategies under the Oxford (1990) Classification of Language Learning Strategies. Zare (2012) stated that cognitive strategies consisted of four sets namely practicing, receiving and sending messages, analysing and reasoning and creating structure for input and output in order for learners to understand and produce the target language. The highest value of percentage is possessed by planning strategy in the statement "l look at the headings'. From the statement, it can be derived that pupils prefer to plan their reading to enhance their understanding while reading. They find it to be helpful for them to know the topic that they are about to read about as it helps to provide them with context. Apart from that, planning strategy is also employed by pupils when they decide to 'look at pictures and what is under the pictures and think about what will come next in the reading'. These two statements indicate that pupils prefer to analyse visual aids provided in the reading materials which then will be used to facilitate the reasoning process. Furthermore, pupils prefer to underline parts that seem to be important, indicating that they are field independent. Brown (2000) defined field independence as a learning style in which it enables a person to distinguish a part from a whole and focus on something without being distracted by other variables. In the final part of the questionnaire, $70 \%$ of pupils or 35 out of 50 pupils stated that they prefer to use dictionaries to find the meaning of words that they are unfamiliar with. This indicates that pupils choose to use dictionaries to overcome problems while reading in 
the target language which will help them to have an in -depth understanding of what they have read.

\section{Implications towards Teaching and Learning}

The findings suggested that the Year 5 and 6 pupils from the four rural schools in Sarawak prefer two types of language learning strategies in their reading lessons. The two language learning strategies are affective and cognitive strategies. In order for teachers to cater to pupils who prefer affective strategy, teachers need to prepare reading worksheets that are based on pupils' interest. In addition, teachers need to tackle pupils' emotions by selecting themes of the learning that they like. This can be done by doing some surveys to know their favourite movies or their hobbies. By integrating pupils' favourite topics and themes in the reading lessons, teachers are able to lower pupils' anxiety levels and create positive and conducive teaching and learning environments for them. As for pupils who prefer cognitive strategy in their reading lessons, teachers need to provide them with reading materials that require them to do analysis and reasoning. $82 \%$ of the respondents look at the headings to understand their reading materials. It is important for teachers to make sure that their reading texts are provided with headings to help these pupils in their teaching and learning process. Reading texts need to be selected carefully and not just randomly picked from books or the internet. On the other hand, $74 \%$ of the respondents think about what will come next in the reading in order for them to understand what they read. Teachers, especially those working in these four rural schools play an important role in developing pupils' cognitive skills. Some of the activities that can be conducted in the reading lessons are identifying keywords and imagery. Teachers should also encourage pupils to ask questions such as what, where, when, why and how, while they are reading a text.

\section{Conclusion}

In a nutshell, conducting Language Learning Strategies surveys help teachers to measure and identify their pupils' learning strategies so that teachers are able to design their teaching and learning activities as well as the worksheets that suit and cater to the needs of their own pupils. According to Macaro (2004), a strategy may not be suitable for all learners. Each pupil has their own learning style and preferences. In addition, pupils who employ more language learning strategies are proven to be better and perform excellently in their learning. Based on the findings of this study which was conducted in selected rural schools in Sarawak, most Year 5 and 6 pupils in the rural schools prefer to use affective and cognitive strategies in their reading lessons. Thus, it is hoped that teachers could plan their reading lessons by considering their pupils' personal preferences as the most important aspect in their planning. For example, pupils who prefer affective strategy in reading should be given materials that are based on their interest as this type of pupils need motivation and positive feelings towards their learning. On the other hand, pupils who prefer cognitive strategy should be encouraged to plan their reading to enhance their understanding while reading. Reading materials with pictures should be given to them often to facilitate them in their reading lessons. Next, teachers could also let the pupils know the result of this survey to such an extent that pupils are aware of how to maximize their learning to improve their reading skill.

\section{References}

Braden, M. J. (2012). Impacting attitudes towards reading in the second grade classroom: a reading role model intervention [Doctoral dissertation, Wichita State University]. 
Chamot, A. U. (2004). Issues in language learning strategy research and teaching. Electronic Journal of Foreign Language Teaching, 1(1), 14-26.

Cohen, A. D., \& Oxford, R. L. (2002). Young learners' language strategy use survey. Styles and strategies-based instruction: A teachers' guide, 75-78.

Cohen, A. D. (2014). Strategies in learning and using a second language. United Kingdom: Routledge.

Dawadi, S. (2017). Language learning strategies profiles of EFL learners in Nepal. Eur. J. Educ. Soc. Sci, 2, 42-55.

Doró, K., and Habók, A. (2013). Language learning strategies in elementary school: the effect of age and gender in an EFL context. J. Linguist. Lang. Teach, 4, 25-37.

Friedrichsen, A. (2020). Second Language Acquisition Theories and What It Means For Teacher Instruction. [Master Thesis, Northwestern College]. Retrieved from https://nwcommons.nwciowa.edu/education_masters

Green, J., \& Oxford, R. L. (1995): A closer look at learning strategies, L2 proficiency, and gender. TESOL Quarterly, 29, 261-297.

Griffiths, C. (2003). Patterns of language learning strategies use. System, 31, 367-83.

Hong, K. (2006). Beliefs about language learning and language learning strategy use in an EFL context: A comparison study of Korean and bilingual Korean-Chinese university students. Dissertation abstracts international, 67(4), 1272.

Khamkhien, A. (2010). Factors affecting language learning strategy reported usage by Thai and Vietnamese EFL learners. Electronic Journal of foreign Language teaching, 7(1), 66-85.

Lavrakas, P. J. (2008). Encyclopedia of survey research methods (Vols. 1-0). Thousand Oaks, CA: Sage Publications, Inc. doi:

10.4135/9781412963947.https://methods.sagepub.com/reference/encyclopedia-ofsurvey-research-methods/n105.xml. [2 June 2021].

Lee, C. K. (2010). An overview of language learning strategies. ARECLS, (7), 132-152.

Liu, J. (2010). Language learning strategies and its training model. Int. Educ. Stud., 3, 100-104.

Macaro, E. (2004). Fourteen features of a language learner strategy. AIS St Helens, Centre for Research in International Education.

Maszlee, M. (2019). Highly Immersive Programme (HIP): An Afternoon with the Minister of Education.

Menezes, V. (2013). Second Language Acquisition: Reconciling Theories. Open Journal of Applied Sciences, 03, 404-412.

Methodology, R. (2015). Convenience sampling - Research Methodology. Retrieved from http://research-methodology.net/sampling/convenience-sampling/

Nazri, M. L. A. (2013). National Language Policy and Its Impacts on Second Language Reading Culture. Journal of International Education and Leadership 3(1): 1-11.

Jalaluddin, N. H., Norsimah, M. A., \& Kesumawati, A. B. (2008). The mastery of English language among lower secondary school students in Malaysia: A linguistic analysis. European Journal of Social Sciences, 7(2), 106-119.

O’Malley, J. M., Chamot, A., Stewner-Manzanares, G., Kupper, L., \& Russo, R. (1985). Learning strategies used by beginning and intermediate ESL students. Language Learning, 35(1), 21-46.

Oxford, R. L. (1990). Language learning strategies: What every teacher should know. New York: Newbury House. 
Pfenninger, S. E., \& Singleton, D. (2017). beyond age effects in instructional L2 learning: revisiting the age factor. Clevedon: Multilingual Matters.

Platsidou, M., \& Kantaridou, Z. (2014). The role of attitudes and learning strategy use in predicting perceived competence in school-aged foreign language learners. J. Lang. Lit., (5), 253-260.

Rao, Z. (2016). Language learning strategies and English proficiency: interpretations from information-processing theory. Lang. Learn. J. 44, 90-106.

Richard, J. C. (1994). Reflective teaching in a second language classroom. New York: Cambridge University Press

Rubin, J. (1975). What the 'good language learner' can teach us. TESOL Quarterly, 9(1), 4151.

Rubin, J. (1987). Learner strategies: Theoretical assumptions, research history and typology. In A. Wenden \& J. Rubin (Eds.). Learner Strategies and Language Learning, 15-29. Englewood Cliffs, NJ, Prentice Hall.

Stern, H. (1992). Issues and options in language teaching. Oxford: Oxford University Press.

The Official Portal of Sarawak Government. (2018). Remembering the Man Who Walked The Talk. Retrieved May 27, 2021, from https://sarawak.gov.my/web/home/news_view/244/10003/.

Wenden, A. L. (1987). Conceptual background and utility. In A. L. Wenden, \& J. Rubin (Eds.). Learner strategies in language learning, 3-13. Englewood Cliffs, NJ: Prentice-Hall.

Williams, M., \& Burden, R. (1997). Psychology for language teachers. Cambridge: Cambridge University Press.

Wu, Y. L. (2008). Language learning strategies used by students at different proficiency levels. Asian EFL J. 10, 75-95.

Yang, H. (2008). On teaching strategies in second language acquisition. Online Submission, 5(1), 61-67.

Zare, Pezhman. (2012). Language learning strategies among EFL/ESL learners: a review of literature. International Journal of Humanities and Social Science, 2(5), 162-169. 